\title{
Coaching children 10 and under with a disability in a multi-sport program
}

\author{
Janet A. Young, Loretta Konjarski \& Rachael Beatson \\ Victoria University, Melbourne, Australia.
}

\begin{abstract}
This paper reports on a review of an Australian-based physical activity program (including tennis) for children 10 and under with a disability. Key features of, and strategies in, this program are highlighted. Implications for coaches to provide inclusive and modified programs for children 10 and under are discussed.
\end{abstract}

Key words: children, disability, inclusion, adapt .

Received: 16 October 2021

Accepted: 25 November 2021

Corresponding author: Janet $\mathrm{A}$. Young. Email: janet_young7@ yahoo.com.au

\section{INTRODUCTION}

\section{The Program}

Victoria University in Melbourne, Australia, conducts a physical activity program for children with a disability (including physical disability, intellectual disability, vision impairment and hearing impairment). The program started in 2005 and, to date, over 1500 children have attended. Currently, the majority of children in the program are aged 10 years and under and they participate in a range of modified activities including tennis (introduced in 2011), soccer, volleyball, netball, bowling and other minor games that focus on fundamental movement and gross motor skills including catching and throwing.

The program is organised and managed by the three authors of this paper with the invaluable coaching assistance of firstyear university students who are enrolled in the Inclusion and Diversity in Physical Education unit. Since 2018, the program consists of four blocks of bi-weekly sessions of 60-minute duration conducted on four basketball courts in an indoor facility close to the university campus. In the first session, groups of 4-8 children (generally from the same school class) with 4-6 coaches are formed. The groups usually continue throughout the block of sessions (but can change due to absences, group and individual needs and Covid-19 lockdowns for example). The children who participate in the program attend Special Developmental schools in the Western suburbs of Melbourne.

\section{Sessions}

The sessions follow 'game-sense' principles (i.e., games versus drills) and start with a group warm-up game (e.g., Follow the Leader or Captain's Treasure), followed by a set of 3-6 activities. These activities are developed, modified and adapted to address the interests and abilities of the children. Examples include relays of passing beanbags on a small racquet and rolling coloured balls with small racquets/ bats around cones. To conclude a session, a group warm-down game (e.g., throwing plastic balls on a large multi-coloured parachute) is conducted.
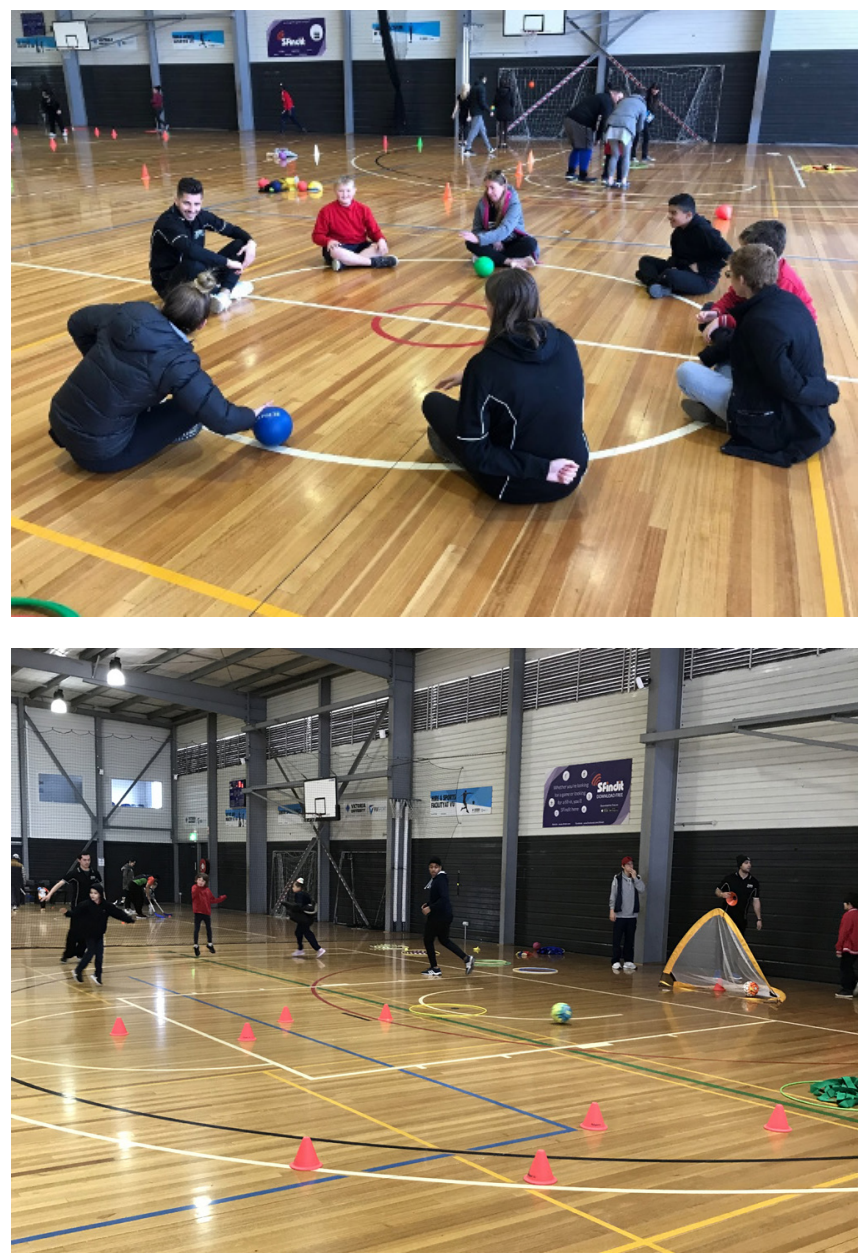

Purpose

The purpose of this paper is to report on a review of this award-winning program. Specifically, what are its key features and strategies adopted that facilitate a safe, fun, engaging and inclusive program? 


\section{PARTICIPANTS}

The three authors of this paper, all academic staff members and coaches at Victoria University, participated in a review of the program. The first two cited authors (above) developed the program in 2005 and have since managed its delivery. The third cited author joined the program in 2018.

\section{PROCEDURE}

Prior to reviewing the program, ethics application was sought but was not required as no data was collected from a third party.

The reviewers/authors were requested to review the program over the last four years when it moved to a neighbouring indoor sporting facility. The reviewers were requested to identify the program's key features, and associated strategies, focusing on the children aged 10 and under who participate in tennis activities.

The reviewers independently made a list of the program's key features and strategies adopted based on their own observations and feedback received from the coaches/firstyear university students and the carers/school teachers who accompanied the children to the program.

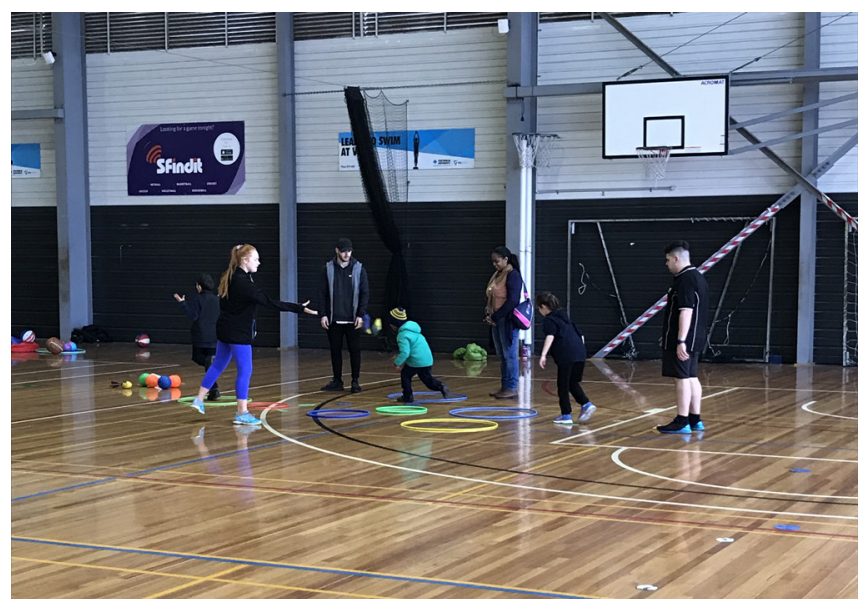

The reviewers' lists of features and strategies were then shared and discussed. Common items were identified and discrepancies between reviewers consensually validated (Patton, 2002).

\section{RESULTS}

The results of the above procedure are shown in the following table.

\section{Table 1}

Key Features and Strategies.

\begin{tabular}{|c|c|}
\hline Key Features & Key Strategies \\
\hline $\begin{array}{l}\text { Engaged and well- } \\
\text { prepared coaches focus on } \\
\text { participation and fun in a } \\
\text { range of non-competitive } \\
\text { activities and games }\end{array}$ & $\begin{array}{l}\text { - Coaches expect, and accept, there might be initial apprehensions and nervousness when first coaching a new group } \\
\text { - Coaches consult with each other, and source relevant material (e.g., Special Olympics Games for Children), to prepare detailed } \\
\text { - Cession plans that include at least } 6 \text { different activities and } 2 \text { 'back-up' activities and safety considerations } \\
\text { - Coaches draw on the children's individual abilities and interests to develop session plans } \\
\text { - Coaches conduct 'mock'/trial sessions with fellow coaches and address feedback } \\
\text { - Coaches encourage and reward participation (score-lines etc have little meaning) }\end{array}$ \\
\hline $\begin{array}{l}\text { Conditions are safe, inviting, } \\
\text { accessible and inclusive }\end{array}$ & $\begin{array}{l}\text { - Coaches conduct a thorough examination of all (including playing) accessible areas prior to sessions } \\
\text { - Coaches are mindful of distancing between individuals/groups and adopt modified, light and easy-to-use equipment } \\
\text { - Coaches assume responsibility to ensure equipment is stored in bins if not being used } \\
\text { - Drink- and rest-breaks are included } \\
\text { - Carers are consulted about medical conditions that may impact on a child's participation where appropriate } \\
\text { - Children are accompanied by a carer for bathroom visits }\end{array}$ \\
\hline $\begin{array}{l}\text { Communications are } \\
\text { predominantly visual and all } \\
\text { are clear, encouraging and } \\
\text { easily understood }\end{array}$ & $\begin{array}{l}\text { - Demonstrations replace instructions and coaches may adopt flash cards, visual aids and pictures to illustrate activities and } \\
\text { behaviours when necessary (e.g., jumping) } \\
\text { - Coaches lead the way and actively participate in the activities (vs acting solely as an observer) } \\
\text { - Lots of smiles, encouragement, positive body language and laughter replace the coaches' spoken words! }\end{array}$ \\
\hline $\begin{array}{l}\text { Individual differences in } \\
\text { abilities and interests are } \\
\text { addressed to ensure all } \\
\text { children can participate and } \\
\text { 'have a go' }\end{array}$ & $\begin{array}{l}\text { - Time is devoted to getting to know each child and their interests and abilities } \\
\text { - Information from carers/school teachers about a child's interests and abilities is sought if children are not joining or enjoying } \\
\text { activities } \\
\text { - Activities match children's interests and abilities with a one-on-one interaction (if sufficient numbers of coaches available) or } \\
\text { coaches adopt 'zones of activity', grouping children with similar abilities and interests to do the same activity }\end{array}$ \\
\hline $\begin{array}{l}\text { Coaches expect, and are } \\
\text { prepared, to adapt activities } \\
\text { to retain interest and } \\
\text { attention and to ensure the } \\
\text { activities suit the skill level } \\
\text { of each child }\end{array}$ & $\begin{array}{l}\text { - Coaches accept changes to planned activities during sessions are likely to be required and prepare accordingly with ways all } \\
\text { activities can be modified or new ones added } \\
\text { - Debriefing sessions for coaches are conducted after sessions when 'success stories' and 'challenging situations' are exchanged } \\
\text { - Coaches are encouraged to keep reflective journals detailing insights gained from sessions }\end{array}$ \\
\hline
\end{tabular}




\section{DISCUSSION}

This paper reports on a review of an Australian-based physical activity program, where tennis is one of the activities, for children 10 and under with a disability. The key features of, and strategies adopted in, the program that were identified in the review (Table 1) are inter-related and linked. Collectively, they support the importance for coaches to be inclusive in the delivery of activities and to encourage children to 'have a go' and 'have fun'.

We suggest the features of, and strategies adopted in, the program are not 'revolutionary' or surprising. Nor are they exclusive to programs for children with a disability. Rather, they endorse well-recognised sound coaching principles including inclusion, preparation, fun, safety and engagement (Martens, 2012). Further, the factors and strategies identified complement the existing literature on coaching children with a disability that advocates everyone should be able to participate in sport and physical activity in a welcoming and inclusive way regardless of ability, prior knowledge and skill level (e.g., SportAus, n.d).

Our program's format to include a variety of games and activities across a number of sports is also consistent with research (e.g., Cote et al., 2009; Sleiman, 2019) supporting a multi-sport and multi-activity approach (versus early specialisation) for long-term developmental and other psychosocial benefits for children.

\section{Implications for coaches}

The authors of this paper suggest coaches may wish to:

- Review their own programs to ensure these provide welcoming opportunities for children with a disability to participate

- Adopt the list of key features and strategies in Table 1 as a checklist when reviewing their programs. We believe our list could be 'a good starting point' when reviewing other programs for children 10 and under and provide clues for practical and effective implementation
- Review the composition of their programs for children 10 and under to include a variety of games and activities (that can be readily modified) across a range of sports in addition to those that relate just to tennis

\section{CONCLUSION}

This paper highlights a number of practical considerations for coaches when working with children 10 and under with a disability (refer to Table 1). Importantly, coaches need to respect and address each child's unique abilities and interests; be well-prepared but willing to adapt and modify; keep activities 'short and sharp'; be mindful of safety; give lots of smiles, encouragement and feedback; and prioritise fun, enjoyment and participation. The program is testament to what can be achieved with a special group of children who are often overlooked by coaches.

\section{CONFLICT OF INTERESTS AND FUNDING}

The authors declare that they do not have any conflict of interest and that they did not receive any funding to conduct the research.

\section{REFERENCES}

Cote, J., Horton, S., MacDonald, D., \& Wilkes, S. (2009). The benefits of sampling sports during childhood. Physical and Health Education Journal, 74(4), 6-11.

Martens, R. (2012). Successful coaching (4th ed.) Human Kinetics

Patton, M. Q. (2002) Qualitative evaluation and research methods. Sage.

Sleiman, M.E. (2019). Does being too specific too young produce good youth athletes but poor adult athletes? Journal of Australian Strength \& Conditioning, 27(2), 86-90.

Special Olympics (Aust.) Resources. https://schools.specialolympics.com.au/ resources

SportAus. (n.d). Inclusive sport. https://www.sportaus.gov.au/integrity_in sport/inclusive_sport

Copyright (C) 2021 Janet A. Young, Loretta Konjarski \& Rachael Beatson

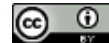

This text is under a Creative Commons BY 4.0 license

You are free to Share - copy and redistribute the material in any medium or format - and Adapt the content - remix transform, and build upon the material for any purpose, even commercially under the following terms:

Attribution: You must give appropriate credit, provide a link to the license, and indicate if changes were made. You may do so in any reasonable manner, but not in any way that suggests the licensor endorses you or your use. 